\title{
Revisiting the Relationship between Justice and Extra-Role Behavior: The Role of State Ownership
}

$\begin{array}{lr}\text { Xi Chen } & 1 \\ & \\ { }^{1} \text { New York University, USA, and }{ }^{2} \text { University of Nottingham Ningbo, China } & 2 \\ & 3 \\ \text { ABSTRACr State ownership is an important phenomenon in the world economy, especially } & 4 \\ \text { in transition economies. Previous research has focused on how state ownership influences } & 4 \\ \text { organizational performance, but few studies have been conducted on how state ownership } & 5 \\ \text { influences employees. I propose that different ownership structures trigger different } & 6 \\ \text { relational models among employees, who pay attention to organizational justice consistent } & 7 \\ \text { with their model to guide their extra-role behavior. Specifically, state-owned organizations } & 8 \\ \text { reinforce employees' relational concern and direct employees' attention to procedural } & 9 \\ \text { justice, whereas privatized organizations highlight employees' instrumental concern and } & 10 \\ \text { direct their attention to distributive justice. I leverage a sample of organizations in China } & 11 \\ \text { to explore how different ownership structures activate different relational models among } & 12 \\ \text { employees and alter the relationship between organizational justice and employees' } & 13 \\ \text { extra-role behaviors. I find that state ownership attenuates and even reverses the positive } & 14 \\ \text { relationship between distributive justice and extra-role behaviors. Conversely, state } & 15 \\ \text { ownership exaggerates the positive relationship between a critical procedural justice } & 16 \\ \text { dimension (participation in decision making) and employee extra-role behaviors. } & 17 \\ \text { Implications for the micro-foundations of corporate governance and institutional change, } & 18 \\ \text { organizational justice literature, and cross-cultural research are developed. This study also } & 19 \\ \text { generates new insights for transition economies such as China. } & 20 \\ & \\ & \end{array}$

\section{INTRODUCTION}

Ownership structure is a key characteristic of corporate governance and holds important implications for organizational strategy and productivity (Hill \& Snell, 1989). State ownership - the degree to which an organization's property interest is vested in the state or a public body representing the state - is still an important phenomenon in the world economy (La Porta, Lopez-De-Silanes, \& Shleifer, 1999). State-Owned Enterprises (SOEs) contribute approximately $10 \%$ of the worlds' GDP (Bruton, Peng, Ahlstrom, Stan, \& Xu, 2015) and still exist in countries including the United States, Germany, France, Italy, China, Brazil (Pargendler, 2012), Canada, the United Kingdom, New Zealand, Finland, Sweden, Hungary, 
Norway, the Philippines, Malaysia, Singapore, Egypt, Serbia, Turkey, Bhutan, Chile, Ghana, Kenya, India, Pakistan, Peru, South Africa, Zambia, Korea, and many other countries (World Bank, 2014). Therefore, Peng, Bruton, Stan, and Huang (2016) suggest that state ownership is one of the mainstream organizational forms and holds important implications for organizational theories. Existing research on state ownership has focused on its implications for organizational performance (Le \& O'Brien, 2010; Ramaswamy, 2001) and found that state ownership is on average associated with decreased labor productivity and corporate performance (Chen, 2001; Xu \& Wang, 1999). However, privatization reform, which aims to reduce state ownership, has only achieved mixed results (Dharwadkar, George, \& Brandes, 2000). Because employees are an important stakeholder of organizations and driver of organizational performance (Aguilera \& Jackson, 2010), how state ownership and its reduction influence employee behavior may provide a clue about the transition effect. However, very few studies have more research is needed on the micro foundation of ownership reform (Cuervo \& Villalonga, 2000; Parker, 1995). A few micro studies found that employees in SOEs prefer egalitarian distribution (He, Chen, \& Zhang, 2004) and perform extra-role behaviors that align with SOEs' goals (Farh, Zhong, \& Organ, 2004). However, it is unclear what motives drive SOE employees to engage in extrarole behaviors. To fill this gap, this study focuses on how organizations with different ownership structure motivate employee behavior that is important for organizational performance - extra-role behavior.

In this study, I propose that SOEs rely on a distinctive mechanism to motivate employees' extra-role behavior. SOEs foster a strong collective identity among employees and encourage them to treat their enterprises as families. This objective is achieved through widespread participation in organizational governance. As the reform emphasizing market efficiency and organizational productivity proceeds, privatized companies reinforce employees' concern about their individual outcomes and utilize equitable allocation of outcomes to motivate employees. Thus, employees in SOEs and privatized companies will hold different relational models about their relationships with their organizations and pay attention to organizational practice that is consistent with their relational model. In particular, I suggest that the communitarian and egalitarian relational model in SOEs accentuates positive reactions to procedural justice, whereas the market and exchange relational model in privatized companies accentuates positive reactions to distributive justice. To test this argument, the present research draws upon the variability in ownership structure of organizations during China's transition to explore how ownership structure moderates the effects of distributive justice and procedural justice on employees' extra-role behavior.

The current work contributes to existing theory and research in a number of ways. First, I bridge micro and macro research on China's economic 
reform (Naughton, 1996; Ramamurti, 2000), developing a theory regarding 76

how ownership structure influences employee relational model and reactions to 77

organizational practices. This is key to understanding the micro-foundations of 78

institutional reform. I suggest that ownership structure is not associated with $\quad 79$

different levels of employee motivation (Burawoy \& Lukacs, 1985), but rather 80

associated with different predictors of employee motivation. Thus, whether these 81

differences are acknowledged and addressed properly during the transition may $\quad 82$

help explain the mixed results of transition effects in macro research. 83

Second, by exploring how ownership structure serves as a key contextual $\quad 84$

factor altering the well-known relationship between organizational justice 85

and extra-role behavior, I offer new insights into the boundary conditions 86

of justice effects. Because different ownership structures rely on different 87

approaches to motivate employees, it will shape which mechanism of justice is $\quad 88$

operative - social exchange or social identity. Specifically, distributive justice, by 89

emphasizing equitable allocation of outcomes, is especially important in soliciting 90

employee extra-role behavior in privatized organizations. Procedural justice, by 91

verifying individuals' collective identity, plays an important role in state-owned 92

organizations. Thus, I show how different justice dimensions matter in different 93

$\begin{array}{ll}\text { contexts. } & 94\end{array}$

Finally, this study holds important implications for designing reform measures $\quad 95$

in transition economies. Previous reform efforts are based on the assumption 96

that SOE managers and employees lack incentives and motivation, and the 97

main reform measure is to privatize SOEs. This study uncovers an unrecognized 98

predictor of employee extra-role behavior in SOEs. I suggest that SOEs do not 99

simply lack motivation but motivate employees in different ways than privatized $\quad 100$

organizations. Recognizing this new motive can generate more creative ways to 101

reform and manage SOEs, given the increasing presence of state ownership around 102

the globe (The Economist, 2012). 103

\section{THEORETICAL BACKGROUND AND HYPOTHESES 104}

In this article, I propose that ownership structure is associated with the relational 105 model that individuals hold regarding their relationships with their organizations 106 and their primary concerns in organizations. Ownership structure and the role $\quad 107$ of labor are two important dimensions in corporate governance (Aguilera \& 108 Jackson, 2010). Because ownership structure defines the social relations among $\quad 109$ organizational actors (Fiss, 2008), it will influence how employees construe their 110 relationships with their organizations. In addition, ownership structure shapes $\quad 111$ organizational goals (Fiss, 2008), which will influence the primary concerns among 112 employees. For instance, a state owner focuses more on organizational solidarity 113 and treats workers as 'master of enterprises' (Chiu, 2006), whereas private owners 114 may focus more on organizational productivity and treat labor as a means to $\quad 115$ achieve organizational productivity. Thus, their relative weights in the ownership 116 
structure of organizations will influence how employees construe their relationships with their organizations - as enterprise master or exchange partners - and whether they are primarily concerned with social identity or exchange outcomes. The relational schemas that employees hold and their primary concerns will direct their attention to different organizational practices (Thornton, Ocasio, \& Lounsbury, 2012), with implications for which form of justice is important for guiding employee extra-role behavior. I selected China as the empirical setting to examine this proposal because its transition from planned economy to market economy generates great diversity in the ownership structure of organizations.

In the context of China, I suggest that state ownership and privatization reform activate different relational models people apply to their organizations. These relational models are the cognitive schemas that people use to process complex information and guide their actions. These cognitive schemas are constructed in a specific institutional environment and mediate the impact of institutions on human behaviors (Seo \& Creed, 2002). Therefore, only one or a few relational models are salient in a specific context, and economic development generally moves the relational model from communal sharing to market pricing (Fiske, 1992). Economic development generally moves the relational schema from communal sharing to market pricing (Fiske, 1992). Applying this theory to employee-organization relationships in China, I argue that the communal sharing model is dominant in SOEs, and the market pricing model is dominant in privatized companies. The following sections will develop these arguments based on previous research.

\section{State Ownership in China}

State ownership is an important characteristic of China's pre-reform socialist economy. China adopted the Soviet model shortly after its revolution (Jackson, 1992), leading SOEs to play a central role in the composition of its planned economy (Groves, Yongmiao, McMillan, \& Naughton, 1994). State ownership is associated with obligations and privileges that have evolved historically. In particular, SOEs have alternative goals beyond financial performance, such as maintaining political stability, increasing employment, and providing public facilities (Walder, 1989; Zif, 1981). In conjunction with these obligations, they have greater access to government loans and purchases and face softer budget constraints (Bai \& Wang, 1998; Dong \& Putterman, 2003). The incentive system of SOEs has been historically characterized by high social benefits and low cash wages (Walder, 1983), both of which are allocated equally within classes of workers (Giacobbe-Miller, Miller, \& Zhang, 1997). SOEs also provide employment security and used to grant all employees lifelong employment until retirement (Naughton, 1996). SOE employees have more secure employment than employees of non-stateowned organizations (Gong \& Chang, 2008).

SOEs' equal treatment of workers in their need satisfaction foster a communal sharing schema (Fiske, 1992) in which those within a group are not differentiated 
and taken care of by the group. Based on interviews with 30 employees and a survey of 500 employees of two SOEs in northeast China, Liu (2003) found that culture is further intensified by the socialist ideology, which regards workers as the 'leading class' and 'master of socialist society' (Wang \& Greenwood, 2015). This ideology cultivated a collective identity of SOE employees as the 'master of enterprises' (zhurenweng) (Chiu, 2006). This identity is manifested in their reactions to unemployment. Due to their sense of class status and entitlement, laid-off workers prevalently experienced loss of face and a sense of betrayal (Mok, Wong, \& Lee, 2002; Wang \& Greenwood, 2015), and state workers resorted to this identity to defend their rights and resist SOEs' downsizing effort, as illustrated in interviews with eight steel SOEs throughout China in 1997 (Hassard, Morris, 169 Sheehan, \& Yuxin, 2006). SOEs' family culture and collective identity have $\quad 170$ been acknowledged by private companies during their acquisition of SOEs, as $\quad 171$ documented in a case study (Xing \& Liu, 2016). The above studies unanimously 172 show that SOEs activate a communal sharing relational model among SOE $\quad 173$ employees, as reflected in their culture and collective identity as 'master of $\quad 174$ enterprises'.

A very important institutional embodiment of that identity is the widespread 176 participation opportunities of SOE employees in the governance of SOEs. 177 SOEs institutionalize widespread employee participation in organizational affairs 178 through daily production meetings, yearly workers' congress, various management 179 committees, and incentive-suggestion systems (Tang, 1993; Walder, 1981). 180 Although these participation opportunities are limited by central planning and 181 party control over leadership selection (Walder, 1981), they still have a symbolic 182 function of enhancing the communal sharing model in SOEs. Based on case 183 studies of six enterprises in Shanghai from 1997 to 1998, Benson and Zhu (1999) 184 found that SOEs are characterized by traditional management systems including 185 teamwork, information sharing, and harmonious work conditions. In these 186 organizations, unions and work congress participate in important organizational 187 decision making, including redundancy decisions, organizational restructuring, 188 developing training, and welfare and housing. In addition, employee creativity 189 is recognized as an asset during ownership transformation, and employees can 190 receive shares or form new companies based on their adopted ideas (Benson \& 191 Zhu, 1999). Participation opportunity has become so deeply grounded in SOE 192 employees' model that they rely on it to evaluate new management practices. 193 For instance, a study of 194 employees from four SOEs in northeast China 194 in 2008 showed that procedural justice, especially being able to participate in $\quad 195$ the performance appraisal process, is very important for employees' perception 196 of the system (Tsai \& Wang, 2013). Therefore, procedural justice, especially 197 the opportunity to participate in organizational decision making, plays an 198 important role in upholding SOE employees' collective identity and sustaining 199 their motivation. 
202 China's economy has experienced an unprecedented change as it transitions from

203 a centrally-planned socialist economy to a market-oriented capitalist economy

204 (Guthrie, 1999). However, the capitalist economy in China is centrally-managed

205 capitalism, where the state plays an important role in many aspects of the

206 economy (Lin, 2011). Under this background, ownership reform in China adopts a

207 gradualist approach, with SOEs coexisting with organizations of hybrid ownership

208 (Nee, 1992). For example, SOEs are partially privatized via public listing on

209 stock exchanges, building joint ventures with local or foreign private firms, or

210 transferring property rights to private holders (Walder, 1995). Analogous to other

211 gradual reforms in China, this privatization reform is only a partial one in

212 the sense that the state remains as a dominant shareholder in many privatized

213 firms. Typically, public listing of SOEs allows the state to retain between $40 \%$

214 and $50 \%$ of the company's shares. Between $20 \%$ and $30 \%$ of the shares are

215 designated for institutional shares, and the remaining $30 \%$ are designated for

216 public consumption as free-floating shares (Guthrie, 1999; Xu \& Wang, 1999). In

217 joint ventures, foreign parent companies often control half or more of the shares

218 of joint ventures, and state-owned parent companies hold the other half or less

219 (Guthrie, 1999). These privatized companies constitute an important sector in

220 China's economy (Walder, 2011). The privatization reform abolished privileges

221 provided by the government, tightened budget constraints, and increased market

222 pressure in privatized companies (Zahra, Ireland, Gutierrez, \& Hitt, 2000). As a

223 result, privatized companies place a higher priority on efficiency and productivity

224 as organizational goals than SOEs do (He et al., 2004).

225 Along with change in ownership structure, management practices of privatized

226 companies are different from SOEs as well. The capitalist market exchanges

227 human activities based on prices generated from market competition (Friedland

228 \& Alford, 1991). Under this logic, privatized companies allocate rewards based

229 on individual performance and contribution to the organization (Giacobbe-Miller,

230 Miller, Zhang, \& Victorov, 2003), provide opportunities for career advancement

231 to motivate their employees (Gong \& Chang, 2008), and use meritocracy as

232 the basis for promotion (Zhao \& Zhou, 2004). That is, the incentive system of

233 privatized organizations follows the rule of equity (Chen, Meindl, \& Hui, 1998).

234 Although SOEs are also increasingly adopting these labor practices, such as

235 bonus payment and piece-rate wages (Groves et al., 1994; Keister, 2002), their

236 movement towards a modern human resource management system is constrained

237 by government involvement and union strength (Benson \& Zhu, 1999). According

238 to a survey of 600 Chinese companies in 2003, SOEs adopt less strategic human

239 resource management practices than foreign-invested enterprises and private-

240 owned enterprises (Ngo, Lau, \& Foley, 2008).

241 With the change in ownership structure and management practices of privatized

242 companies, the relationship between employees and their organizations change as 
well. As privatized companies reward individuals according to their contribution, employees will adopt the market pricing model - in which they view their organizations than SOE employees, due to their common interest in the exchange relationship.

Overall, previous research has found a significant difference between SOEs and privatized companies in organizational practices and employee models. SOEs create a family culture and activate a communal sharing model among employees. Accordingly, SOE employees participate widely in organizational activities and develop the collective identity as 'master of enterprises'. In contrast, privatized

\section{Organizational Justice and Extra-Role Behavior}

An important indicator of employees' contribution to their organizations is extra- 
partly justify the existence of organizations within markets by lowering transaction costs and increasing coordination at little tangible cost to the firm (Coase, 1937; Williamson, 1981). Previous research has found that the ownership structure of organizations is related to different forms of extra-role behaviors that individuals perform (Farh et al., 2004). For instance, because SOEs incorporate social welfare as an indicator of organizational performance, SOE employees engage more in behaviors that are community-oriented, such as participating in social welfare, than non-SOE employees. On the other hand, because SOEs place a lower emphasis on organizational efficiency than non-SOEs, SOE employees engage less in extra-role behaviors that enhance organizational efficiency - such as taking initiatives and saving and protecting organizational resources - than non-SOE employees. In the current study, I take a different perspective and focus on extra-role behaviors that have been widely regarded as important to all kinds of organizations. I examine how ownership structure influences predictors of these extra-role behaviors that are essential for organizational effectiveness.

I argue that ownership reform changes people's models of their relationships with organizations, and the different relational models of employees in SOEs and privatized companies will lead them to pay attention to different organizational practices. Perceived justice is an important way through which organizational practices increase employees' extra-role behaviors. Organizational justice includes distributive justice - the allocation of outcomes according to individuals' performance and contribution - and procedural justice - the fair process of organizational decision making, such as allowing individuals to participate (Colquitt, 2001). Both distributive justice and procedural justice robustly predict employees' motivation and extra-role behaviors (Cohen-Charash \& Spector, 2001). However, individuals don't take all forms of justice into consideration when making a decision about their extra-role behaviors (Lind, 2001). Instead, they rely on the most salient form of justice in their environment to make an overall evaluation of their organization and rely on that evaluation to guide their extra-role behaviors (Lind, Kray, \& Thompson, 2001). Based on relational models theory (Fiske, 1992), I propose that which form of justice becomes salient in a context will depend on the relational model in that context because relational model guides individuals' information processing. Information that is consistent with the model is attended to and becomes salient, whereas information that is inconsistent with the model is ignored or downplayed (Fiske, 1992; Sanchez-Burks, Nisbett, \& Ybarra, 2000). As a result, the salience of distributive justice and procedural justice in a specific context depends on the dominant relational model in that context.

Based on cross-cultural research, I suggest that distributive justice is especially salient under the market pricing model, whereas procedural justice is especially salient under the communal sharing model. When people hold the market pricing model, they are primarily concerned with the ratio of their output to their input, which is exactly the definition of distributive justice (Adams, 1965). Social exchange theory suggests that individuals strive to maximize the resources they receive 
in social exchanges, and distributive justice makes sure that individuals' inputs

\section{The Moderation Effect of Ownership Structure}

In this section, I argue that the effects of organizational justice will depend on the

I propose that the communal sharing model in SOEs reinforces the importance 365 of procedural justice in verifying employees' collective identity. Scholars have $\quad 366$ drawn upon social identity theory to explain why procedural justice elicits 
extra-role behaviors - described in the group engagement model (Tyler \& Blader, 2003). This model suggests that organization members have a need to belong to the organization and therefore identify with it (Lind \& Tyler, 1988; Tyler, 1989), and procedural justice satisfies that need because it enhances members' sense of pride and respect (Tyler \& Blader, 2000). I argue that this identity mechanism of justice is especially salient in highly state-owned organizations, where employees hold the communal sharing model and value their organizational membership. Because procedural justice enhances their pride about their organizational membership and makes them feel respected and honored in SOEs, it leads them to invest their social identities in their organizations and engage in extra-role behaviors to express that identity. Thus, employees in state-owned organizations will display a stronger positive reaction to procedural justice via extra-role behaviors than those in organizations with lower levels of state-ownership.

Hypothesis 1: State-ownership will moderate the positive relationship between procedural justice and employee extra-role behaviors, such that the relationship will be stronger for employees of organizations with higher levels of state ownership.

In privatized companies, where employees are more concerned about their economic outcomes, I propose that distributive justice will be a more important driver of individual extra-role behaviors than in SOEs. According to social exchange theory, both justice and extra-role behavior are social resources used in the exchange between organizations and employees, and their exchange follows the rule of reciprocity (Colquitt et al., 2013). This is consistent with the market pricing model, which matches input to output proportionally (Fiske, 1992). As employees of privatized organizations view their relationship with organizations as exchanges, they will match their extra-role behaviors to the outcomes received from their organizations. When these employees perceive the outcomes they receive from organizations to be fair, they will reciprocate by engaging in extra-role behavior. In addition, distributive justice may lead employees to increase extra-role behavior to exchange for outcomes they value. Although extra-role behaviors are not prescribed in role-definitions, employees deem these behaviors instrumental to increase their performance evaluation and promotion opportunities (Hui, Lam, \& Law, 2000; MacKenzie, Podsakoff, \& Fetter, 1991). When people perceive their companies to be fair and believe these behaviors are reciprocated by their organizations, they are more likely to engage in extra-role behaviors (Podsakoff, MacKenzie, Paine, \& Bachrach, 2000). Taken together, employees of privatized organizations will pay more attention to distributive justice to make a decision about whether to engage in extra-role behaviors than SOE employees. Therefore, I hypothesize that:

Hypothesis 2: State-ownership will moderate the positive relationship between distributive justice and employee extra-role behaviors, such that the relationship will be stronger for employees of organizations with lower levels of state ownership. 


\section{QUALITATIVE STUDY}

\section{Sample and Procedure}

Because Fiske (1992)'s relational models are targeted to interpersonal relationships, existing measures of relational modles - such as Haslam and Fiske (1999) are not suitable to characterize employee-organization relationships in this study. models under different ownership structures. This is consistent with the qualitative methodology employed in research of relational models (Fiske, 1991). In order to

The interviews were conducted at the managers' offices. The interviews were

\section{Results}

The management practices of the four cases are summarized in Table 1. Because 
Table 1. Organizational information of state-owned enterprises, public firms, and joint ventures. Summary of case organizational information

\begin{tabular}{|c|c|c|c|}
\hline Case Number & 1 & 2,3 & 4 \\
\hline State Ownership & $100 \%$ & $47 \%, 45 \%$ & $30 \%$ \\
\hline Organizational type & SOE & Public Firm & Joint Venture \\
\hline Organizational goals & $\begin{array}{l}\text { Fealty to state, } \\
\text { Contribution to } \\
\text { economy, Harmony } \\
\text { of top management } \\
\text { team, Employee } \\
\text { satisfaction }\end{array}$ & $\begin{array}{l}\text { Board evaluation, } \\
\text { Continuous profit, } \\
\text { Functional } \\
\text { coordination, } \\
\text { Industry reputation }\end{array}$ & $\begin{array}{l}\text { Brand recognition, } \\
\text { Product quality, Market } \\
\text { share, Personnel } \\
\text { development }\end{array}$ \\
\hline Board composition & $\begin{array}{l}\text { Party secretary, Top } \\
\text { management team }\end{array}$ & $\begin{array}{l}\text { Party secretary, Top } \\
\text { management } \\
\text { team,Independent } \\
\text { board members, } \\
\text { Union representative }\end{array}$ & $\begin{array}{l}\text { Delegates of parent } \\
\text { companies }\end{array}$ \\
\hline $\begin{array}{l}\text { Organizational } \\
\text { structure }\end{array}$ & $\begin{array}{l}\text { Simple } \\
\text { Three functional } \\
\text { departments }\end{array}$ & $\begin{array}{l}\text { Complex } \\
\text { Multiple functional } \\
\text { departments }\end{array}$ & $\begin{array}{l}\text { Simple } \\
\text { Multiple functional } \\
\text { departments }\end{array}$ \\
\hline $\begin{array}{l}\text { Performance } \\
\text { evaluation }\end{array}$ & No evaluation & $\begin{array}{l}\text { Key-Performance } \\
\text { Indicators } \\
\text { Balanced Score Card }\end{array}$ & $\begin{array}{l}\text { Goal achievement } \\
\text { Self-evaluation } \\
\text { Supervisor evaluation }\end{array}$ \\
\hline Compensation & $\begin{array}{l}\text { Fixed wages } \\
\text { No evaluation-based } \\
\text { bonus }\end{array}$ & $\begin{array}{l}\text { External } \\
\text { competitiveness } \\
\text { Internal fairness }\end{array}$ & $\begin{array}{l}\text { Job requirements } \\
\text { Individual performance } \\
\text { Market competitiveness }\end{array}$ \\
\hline Training & Basic position training & $\begin{array}{l}\text { Monthly safety } \\
\text { training } \\
\text { Continued education } \\
\text { EMBA for top } \\
\text { managers }\end{array}$ & $\begin{array}{l}\text { Externally required/ } \\
\text { madatory training } \\
\text { Individual skill training } \\
\text { Education sponsorship } \\
\text { policy }\end{array}$ \\
\hline Participation & $\begin{array}{l}\text { Worker congress } \\
\text { meeting } \\
\text { Incentive-suggestion } \\
\text { system }\end{array}$ & $\begin{array}{l}\text { Worker congress } \\
\text { meeting } \\
\text { Incentive-suggestion } \\
\text { system }\end{array}$ & $\begin{array}{l}\text { Informal } \\
\text { communication } \\
\text { Incentive-suggestion } \\
\text { system }\end{array}$ \\
\hline
\end{tabular}

447 goals, employee satisfaction was one of organizational goals in SOEs, but not in 448 public firms or joint ventures, indicating the special employee status in SOEs. 449 According to company law in China, limited companies with two or more state450 owned investors need to have a union representative on the board to represent the 451 interest of workers, as reflected in Cases 2 and 3. These characteristics indicate 452 that in SOEs and public firms, employee satisfaction is an ends rather than a 453 means to achieve organizational profit. This is different from the schema in highly 454 privatized organizations, such as the joint venture. Their organizational goals 455 focus on personnel development, which treats employees as human resources for 
achieving organizational goals. Therefore, different organizational goals regarding employees reflect different relational models.

In SOEs, employees rely on their organizations to satisfy their needs, reflecting the communal sharing schema (Fiske, 1992). An SOE manager commented about SOE employees' loyalty (Case 1):

The workers of SOEs are very loyal. They think that they belong to the firm even after death, visit them. I buy employees casualty insurance. If they get cancer, I give them 100,000 Yuan. I visit them during holidays. If an employee dies, I cover a series of services. Overall, employee loyalty is highest in SOEs, less in public firms, and even less in joint ventures.

Another SOE manager commented about the organizational culture of the

With the development of the times, employees of SOEs are not as committed as in the past.

SOEs and public firms hold annual worker congress meetings, which

I have a series of democratic management procedures, including employee representative meetings,

The public firms and the joint venture inherited the incentive-suggestion system (helihua jianyi) from former SOEs, in which employees provide suggestions for improving the work process and receive recognition or bonuses (in case 4) for their valuable suggestions. Yet in the joint venture, employees' suggestions become responsible for making decisions, and employees are to execute decisions. Their communication is mostly carried out in the informal way, in which employees directly express their concerns to their supervisors.

The incentive systems are different between the three kinds of organizations evaluation or performance-based bonus for employees. The equality in outcomes 
et al., 1998). The joint venture evaluates and rewards individual performance consistent with the market pricing model. Their incentive system emphasizes not only internal equity but also external competitiveness, i.e., it ensures that employees are compensated for the value they create for their organizations. A joint venture manager, who was dispatched to the joint venture from an SOE in 2009, described the incentive system of joint ventures this way (Case 4):

Our system is objective, scientific, and based on data and evidence. It's not like SOE, where bonuses often come as surprises. The incentive system gave priority to performance in evaluation, reward, and promotion. The organization and managers and employees at each level set goals at the beginning of every year. With reference to the goals, the evaluation of employees is carried out every year, combining self-evaluation and supervisor evaluation. The compensation is based on the result of evaluation, adjusting up to $20 \%$ above or below the salary band for each level. The salary levels are adjusted annually for market competitiveness by comparing with market salary data.

The public firms were experimenting with different evaluation and incentive systems, such as Key-Performance Indicators (KPI) and balanced score card and experiencing some tension during the transition. A public firm manager described the challenges that she encountered in enforcing the new incentive systems (Case 3). Because the firm used to be SOE, employees still held the communal sharing model and react negatively to the management practices that contradict this model.
I have established all the institutions relying on economic measures. However, when the (firm) performance is not good, I can't enforce these institutions, because I don't have so much money. SOE employees are not as qualified (su zhi) as joint venture employees, and their attitudes are not good. When you evaluate their performance, they think that you are going to deduct their wages. Therefore, I can't do performance evaluation right now. The rules can't rule the mass (fa bu ze zhong). I will hold KPI trainings this year.

The interviews and case studies corroborated my argument that highly stateowned organizations activate a communal sharing model whereas highly privatized organizations reinforce a market pricing model. The evidence provided support for my theoretical argument that different relational models underlie different ownership structures. The following quantitative study further tests my hypotheses regarding how ownership structure moderates employees' reactions to different justice practices.

\section{QUANTITATIVE STUDY}

Utilizing the ownership diversity of organizations in China, this study examines the moderating effect of state ownership on individual behaviors in a variety of firms located in Shanghai, China. The quantitative study was conducted with Shanghai State-owned Assets Supervision and Administration Commission (SASAC) from 


\section{Sample and Procedure}

Among the 40 group companies supervised by Shanghai SASAC, four agreed education.

The questionnaire was translated from English to Chinese by the author 


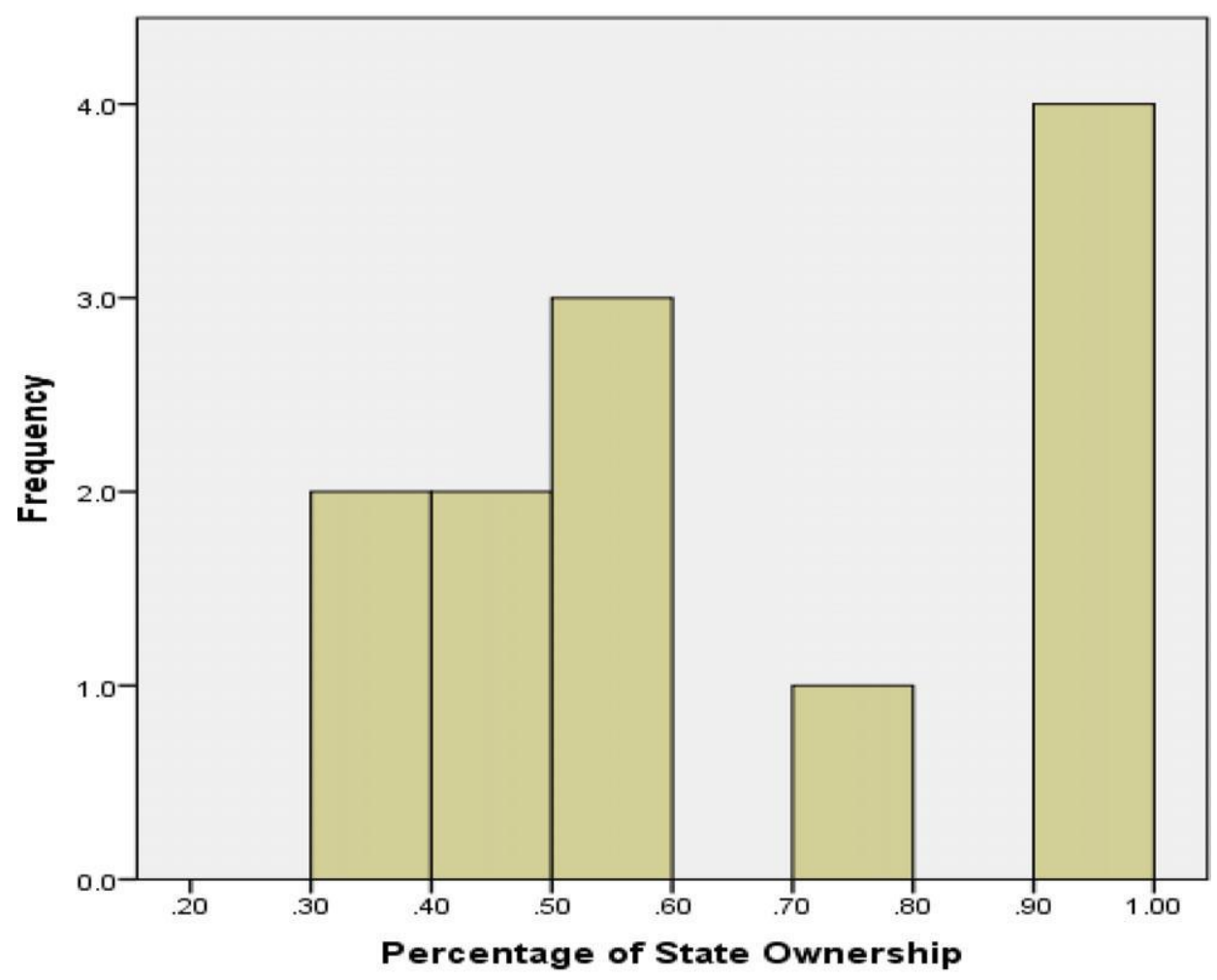

Figure 1. (Color online) Histogram of state ownership in 12 organizations.

the anonymity of their responses. They were required to seal the envelopes after completing the survey and drop the envelopes at a central location. After the survey, the companies returned the envelopes to the author.

\section{Measures}

Independent variables. I obtained the annual statistics of all the firms from the government office and calculated the degree of state ownership by the proportion of state-owned equity in the total equity of each organization, following the example of previous research (Le \& Buck, 2009; Le \& O'Brien, 2010). The information of state-owned equity was readily available in the government report (SASAC, 2008), and the total equity was calculated by subtracting total liabilities from total assets. The distribution of state ownership in the sample is presented in Figure 1. Following the example of previous literature (Colquitt, 2001), distributive justice was measured by the extent to which the outcomes are allocated based on individual contribution. I selected a scale widely used in previous studies (Blader \& Tyler, 2009; Tyler \& Blader, 2000, 2003). This scale contained five items, including 'The resources I receive are linked to how well I do my job' and 'In general, 
resources are fairly allocated among employees at my organization' $(\alpha=0.91)$.

One of the most important manifestations of procedural justice is organizational members' participation in organizational decision making (Bies \& Shapiro, 1988), and the function of participation in conveying the relational value of procedural justice has been found to be cross-cultural (Lind, Tyler, \& Huo, 1997). Therefore, I measured procedural justice with a scale asking about employees' participation in organizational decision making (Hage \& Aiken, 1969). The scale has four adoption of new programs?' and 'How frequently can you participate in decisions

Dependent variable. Since my objective is to examine extra-role behavior that is role behavior that represents individuals' engagement with organizations (Blader \& Tyler, 2009; Tyler \& Blader, 2000, 2003). With a five-point scale ranging from 1'never' to 5-'always', respondents rated the frequency of how often they engage in six behaviors, such as volunteering to do things that are not required in order to help the organization; putting extra effort into doing their jobs well, beyond what is normally expected; working extra hours even when they would not receive credit

Control variables. I controlled for demographic variables including gender, education, research (Morrison, 1994; Podsakoff et al., 2000). Gender was a dummy variable ( $1=$ Female, $0=$ male), whereas the other variables were treated as continous variables. Previous research suggests that another dimention of organizational justice - also influences their extra role behavior (Colquitt, 2001). Therefore, this study controlled for interactional justice, which was measured with a four-item scale used in previous research (Blader \& Tyler, 2003a, 2003b). Respondents indicated to what extent their supervisors consider their views, respect their rights, care about employees' well-being, and give them an explanation for the decisions made when there is a disagreement (1-highly disagree, 5-highly agree; $\alpha=0.92$ ). In order to rule out the alternative argument that the effect of state ownership included psychological collectivism and interdependent self-construal, which have or moderate the effect of procedural justice (Brockner et al., 2005). Psychological collectivism is individuals' value of groups and was measured by selecting five items with the highest loadings on each dimension of the psychological collectivism scale 
preferred to work in groups rather than working alone'; 'I felt comfortable trusting group members to handle their tasks'; 'I followed the norms of groups'; 'I was concerned about the needs of groups'; and 'Group goals were more important to me than my personal goals' (1-highly disagree, 5-highly agree; $\alpha=0.85$ ). I measured interdependent self-construal with four items with the highest loadings in the relational-interdependent self-construal scale (Cross, Bacon, \& Morris, 2000): 'my close relationships are an important reflection of who I am'; 'when I feel very close to someone, it often feels to me like that person is an important part of who I am'; 'I think one of the most important parts of who I am can be captured by looking at my close friends and understanding who they are'; and 'when I think of myself, I often think of my close friends or family also' (1-highly disagree, 5-highly agree; $\alpha=0.71)$.

\section{Results}

Firstly, I tested whether missing data was a serious problem in the sample.

Missing value analysis showed that the majority of missing values occurred in the demographic variables (the number of observations for other variables ranged from 716 to 721). I divided the sample into two subsamples: one without any missing values of gender, tenure, education, and position $(\mathrm{N}=464)$, and the other with at least one missing value $(\mathrm{N}=255)$. The two subsamples did not have a significant difference on extra-role behaviors $(t(458)=1.63, \mathrm{p}=0.10)$. Therefore, missing data did not cause a serious concern. After that, I also examined whether SOEs and privatized organizations differ in age or tenure because of the different histories of these organizations. ANOVA results showed that SOEs, public firms, and joint ventures did not have a significant difference on employee age $(F(2,646)=1.00$, $\mathrm{p}=0.37)$ or tenure $(\mathrm{F}(2,596)=2.65, \mathrm{p}=0.07)$.

Secondly, I conducted confirmatory factor analysis to examine whether the measurement of variables was valid. The confirmatory factor analysis showed that the six-factor model, using all the items of the measured variables without parceling, fit very well with the data $\left(\chi^{2}(390)=1579.68, \mathrm{p}<0.001, \mathrm{CFI}=\right.$ 0.92 , TLI $=0.91$, RMSEA $=0.06$ ). In order to examine whether a substantial common method variance was present, I conducted the one-factor test as suggested in previous studies (Podsakoff, MacKenzie, Jeong-Yeon, \& Podsakoff, 2003). The model that loaded all the items on a common method factor did not fit the data well $\left(\chi^{2}(405)=7234.70, \mathrm{p}<0.001, \mathrm{CFI}=0.52, \mathrm{TLI}=0.48, \mathrm{RMSEA}\right.$ $=0.15)$, which suggested that the common method cannot account for the relationship between variables. I also compared the measurement model with several alternative models. For instance, the six-factor model fit better than a fivefactor model that combined distributive justice and procedural justice $\left(\chi^{2}(5)=\right.$ $1207.72, \mathrm{p}<0.001$ ) and a four-factor model that combined distributive justice,

procedural justice, and leader treatment $\left(\chi^{2}(9)=2172.27, \mathrm{p}<0.001\right)$. These comparisons suggest that distributive justice, procedural justice, and interactional 
justice measured in this study represent distinctive aspects of organizational justice.

I also compared the measurement model with a five-factor model that combined psychological collectivism and interdependent self-construal, and the latter fit the data significantly worse $\left(\chi^{2}(5)=219.49, \mathrm{p}<0.001\right)$, indicating that collectivism and interdependent self-construal represent distinctive aspects of cultural values.

The means, standard deviations, and correlations among all the variables are presented in Table 2.

Thirdly, I used the software HLM7 to test my hypotheses. Considering the nested nature of my data, I constructed a three-level hierarchical linear model to control for industry and firm effects. The results are presented in Table 3 . In the intercept-only model, both firm effects and industry effects were significant, which indicated the necessity of controlling for these effects. In Model 1, I entered the demographic variables into the model. Both position and tenure had significant and positive effects on extra-role behaviors. To test my hypotheses that state ownership accentuates the effect of procedural justice (H1) and attenuates the effect of distributive justice $(\mathrm{H} 2)$ on extra role behavior, I centered procedural justice and distributive justice around their group means and centered state-ownership around its grand mean, following the suggestion of previous research (Aguinis, Gottfredson, \& Culpepper, 2013). ${ }^{[2]}$ In Model 2, I entered state ownership, distributive justice, and procedural justice into the model. Consistent with previous research, both distributive justice and procedural justice had significant and positive effects on extra-role behaviors. To test the moderation effect of state ownership, I entered these interaction terms in Model 3. The interaction effects significantly improved model fit $\left(\chi^{2}(2)=11.74, p=0.003\right)$ and explained $3 \%$ of individual-level variance and $5 \%$ of industry-level variance according to the procedure suggested by Hox (2010). According to Cohen's standard, the effect sizes were above the low level (0.02) and under the medium level (0.15). Besides the variances explained which indicate explanatory power, Aguinis et al. (2013) also recommended reporting predictive power as indicated by the coefficients of moderation effect. The interaction effect between state ownership and procedural justice $(\gamma=0.30)$ was significant and positive, which supported H1. This effect has achieved the medium standard of effect size (Cohen, 1988). I did a simple slope analysis at one standard deviation above, at, and below the mean level of state ownership (Preacher, Curran, $\&$ Bauer, 2006) and plotted the simple slopes in Figure 2. Simple slope analysis showed that the effect of procedural justice on extra-role behaviors was positive at high ( simple slope $=0.21$ s.e. $=0.05, t=4.19, p<0.001)$ and medium levels (simple slope $=0.14$, s.e. $=0.04, t=3.94, p=0.001$ ) of state ownership, but the effect became non-significant at low level of state ownership (simple slope $=0.07$, s.e. $=0.05, t=1.58, p=0.115)$.

In Model 3 of Table 3, the interaction effect between state ownership and distributive justice was significant and negative; supporting $\mathrm{H} 2$ that state ownership attenuates the positive effect of distributive justice on extra-role behaviors. The 680 
Table 2. Correlations and descriptive statistics ${ }^{\mathrm{a}}$

\begin{tabular}{|c|c|c|c|c|c|c|c|c|c|c|c|c|}
\hline Variables & Mean & $S D$ & 1 & 2 & 3 & 4 & 5 & 6 & 7 & 8 & 9 & 10 \\
\hline 1. State ownership & 0.64 & 0.25 & & & & & & & & & & \\
\hline 2. Procedural Justice (Participation) & 2.51 & 1.06 & -0.03 & 0.90 & & & & & & & & \\
\hline 3. Distributive Justice & 3.51 & 0.71 & -0.09 & 0.52 & 0.91 & & & & & & & \\
\hline 4. Extra-role behavior & 3.66 & 0.70 & -0.16 & 0.43 & 0.35 & 0.91 & & & & & & \\
\hline 5. Interactional justice & 3.70 & 0.67 & -0.13 & 0.41 & 0.67 & 0.42 & 0.92 & & & & & \\
\hline 6. Psychological collectivism & 3.97 & 0.52 & -0.12 & 0.31 & 0.42 & 0.56 & 0.49 & 0.85 & ong & & & \\
\hline 7. Interdependent self-construal & 3.58 & 0.55 & 0.04 & _ 0.23 & _ 0.32 & _0.35 & _ 0.30 & _ 0.46 & _0.71 & & & \\
\hline 9. Education & 3.31 & 1.12 & - 0.08 & 0.19 & -0.01 & 0.16 & 0.11 & 0.08 & 0.07 & - 0.01 & & \\
\hline 10. Position & 1.96 & 1.00 & _ 0.04 & 0.46 & 0.18 & 0.27 & 0.18 & 0.16 & 0.14 & - 0.12 & 0.36 & \\
\hline 11. Tenure & 13.29 & 9.75 & 0.00 & -0.04 & $\begin{array}{r}0.11 \\
-\end{array}$ & 0.04 & -0.17 & -0.06 & 0.01 & -0.08 & -0.320 .11 & \\
\hline
\end{tabular}

Notes: ${ }^{\mathrm{a}}$ Entries on the diagonal are Cronbach's alphas. Significance levels are based on two-tailed tests. For position, $1=$ Employee, $2=$ Supervisor, $3=$ Middle manager, $4=$ Top manager. For education, 1 = Middle school, 2 = High school, 3 = College, 4 = Bachelor, 5 = Master or higher.

$\mathrm{p}<0.05 ; \quad \mathrm{p}<0.01$ 
Table 3. Hierarchical linear models of extra-role behavior

\begin{tabular}{|c|c|c|c|c|c|c|c|c|c|c|c|c|c|c|c|}
\hline \multirow[b]{2}{*}{ DV: Extra-role behavior } & \multicolumn{3}{|c|}{ Intercept-only model } & \multicolumn{3}{|c|}{ Model 1} & \multicolumn{3}{|c|}{ Model 2} & \multicolumn{3}{|c|}{ Model 3} & \multicolumn{3}{|c|}{ Model 4} \\
\hline & & s.e & $\mathrm{p}$ & $\mathrm{b}$ & s.e & $\mathrm{p}$ & $\mathrm{b}$ & s.e & $\mathrm{p}$ & $\mathrm{b}$ & s.e & $\mathrm{p}$ & $\mathrm{b}$ & s.e & $\mathrm{p}$ \\
\hline Intercept & 3.63 & 0.12 & $<0.001$ & 3.18 & 0.15 & $<0.001$ & 3.23 & 0.14 & $<.001$ & 3.19 & 0.14 & $<0.001$ & 3.26 & 0.12 & $<0.001$ \\
\hline State ownership & & & & & & & -0.36 & 0.22 & 0.138 & -0.36 & 0.22 & 0.137 & -0.39 & 0.17 & 0.058 \\
\hline Female & & & & -0.08 & 0.06 & 0.15 & -0.03 & 0.06 & 0.58 & -0.04 & 0.06 & 0.533 & -0.06 & 0.05 & 0.279 \\
\hline Education & & & & 0.04 & 0.03 & 0.22 & 0.06 & 0.03 & 0.048 & 0.07 & 0.03 & 0.016 & 0.07 & 0.03 & 0.015 \\
\hline Position & & & & 0.15 & 0.03 & 0.001 & 0.07 & 0.03 & 0.038 & 0.07 & 0.03 & 0.041 & 0.05 & 0.03 & 0.094 \\
\hline Tenure & & & & 0.01 & 0.00 & 0.04 & 0.01 & 0.00 & 0.01 & 0.01 & 0.00 & 0.01 & 0.01 & 0.00 & 0.003 \\
\hline PJ & & & & & & & 0.13 & 0.04 & 0.001 & 0.14 & 0.04 & 8.001 & 0.13 & 0.03 & $<0.001$ \\
\hline PJ state ownership & & & & & & & & & & 0.30 & 0.14 & 0.038 & 0.32 & 0.13 & 0.013 \\
\hline & & & & & & & 0.14 & 0.05 & 0.003 & 0.13 & 0.05 & 0.005 & -0.08 & 0.05 & 0.12 \\
\hline DJ state ownership & & & & & & & & & & 0.69 & 0.20 & 0.001 & 0.79 & 0.19 & 0.001 \\
\hline Interactional justice & & & & & & & & & & & & & -0.12 & 0.06 & 0.027 \\
\hline Collectivism & & & & & & & & & & & & & 0.46 & 0.06 & $<0.001$ \\
\hline ISC & & & & & & & & & & & & & 0.10 & 0.05 & 0.04 \\
\hline Collectivism DJ & & & & & & & & & & & & & - 0.07 & 0.08 & 0.382 \\
\hline Collectivism PJ & & & & & & & & & & & & & 0.07 & 0.06 & 0.231 \\
\hline ISC DJ & & & & & & & & & & & & & -0.14 & 0.08 & 0.082 \\
\hline ISC PJ & & & & & & & & & & & & & $\begin{array}{r}0.02 \\
-\end{array}$ & 0.06 & 0.704 \\
\hline Random part & & Var & $p$ & & Var & $p$ & & Var & $p$ & & Var & $p$ & & Var & $p$ \\
\hline$\sigma^{2}$ individual & & 0.43 & & & 0.36 & & & 0.33 & & & 0.32 & & & 0.26 & \\
\hline$\sigma^{2}$ firm & & 0.03 & 0.001 & & 0.02 & $<.001$ & & 0.02 & 0.001 & & 0.02 & 8.001 & & 0.01 & 0.004 \\
\hline$\sigma^{2}$ industry & & 0.04 & 0.002 & & 0.02 & 0.011 & & 0.01 & 0.013 & & 0.01 & 0.016 & & 0.00 & 0.086 \\
\hline $\mathrm{R}^{2} \quad$ individual & & & & & 0.17 & & & 0.09 & & & 0.03 & & & 0.19 & \\
\hline $\mathrm{R}^{2}$ firm & & & & & 0.43 & & & 0.15 & & & 0 & & & 0.42 & \\
\hline $\mathrm{R}^{2}$ industry & & & & & 0.57 & & & 0.16 & & & 0.05 & & & 0.69 & \\
\hline Deviance & & 1460. & (4) & & $858.98(8)$ & & & $811.70(11)$ & & & $799.96(13)$ & & & $599.79(20)$ & \\
\hline
\end{tabular}

Notes: ISC=Interdependent Self-Construal. DJ= Distributive justice. PJ= Procedural justice (participation). For position, $1=$ Employee, $2=$ Supervisor, $3=$ Middle manager, $4=$ Top manager. For education, 1 = Middle school, 2 = High school, 3 = College, 4 = Bachelor, 5 = Master or higher. 


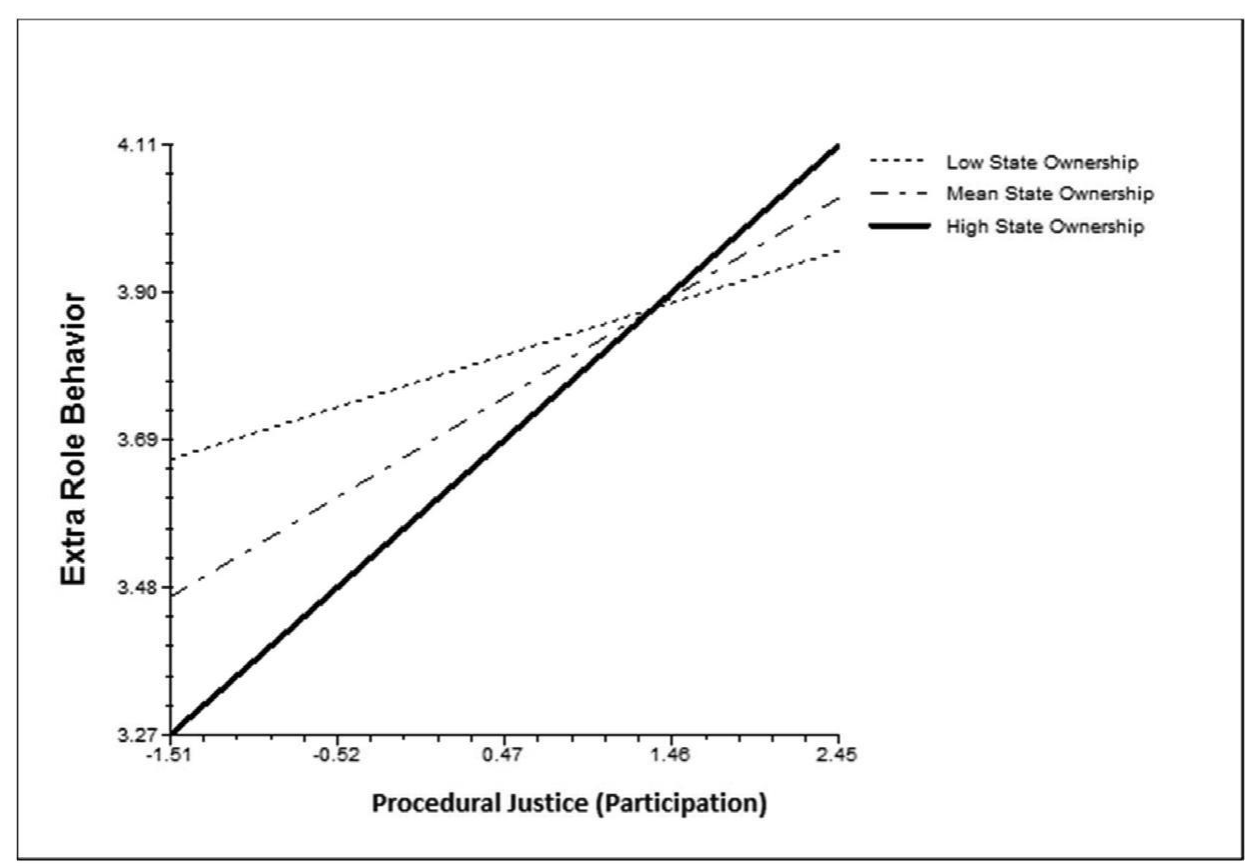

Figure 2. The interaction effect of procedural justice and state ownership on extra-role behavior.

717 (above 0.50) (Cohen, 1988). The results of simple slope analysis are presented in

718 Figure 3. Distributive justice had a positive effect on extra-role behaviors among 719 organizations with medium (simple slope $=0.13$, s.e. $=0.05, t=2.83, p=0.005$ ) or

720 low levels (simple slope $=0.29$, s.e. $=0.06, t=4.54, p<0.001$ ) of state ownership.

721 At high level of state ownership, distributive justice did not have a significant effect on extra-role behaviors (simple slope $=-0.03$, s.e. $=0.07, t=-0.43, p=0.66$ ).

Finally, I conducted robustness checks to test whether the moderation effects of state ownership are driven by individual differences on collectivism and interdependent self-construal. To achieve that objective, I first tested whether state ownership was associated with cultural values. I regressed cultural values on state ownership in hierarchical linear models. After controlling for demographic variables, state ownership did not have a significant effect on psychological collectivism $(b=-0.05$, s.e. $=0.16, \mathrm{p}=0.76)$ or interdependent self-construal $(b$ $=0.00$, s.e. $=0.11, p=0.99)$. Therefore, state ownership was not systematically related with individual difference in cultural values. Next, I entered cultural values

732 and their interaction effects with distributive justice and procedural justice in the

733 model. In Model 4 of Table 3, both psychological collectivism and interdependent

734 self-construal had a significant and positive effect on extra role behavior.

735 Controlling for these effects and their moderating effects, the hypothesized

736 interaction effects remained significant. It indicates that the moderation effects

737 of state ownership were not due to individual differences on collectivism,

738 interdependent self-construal, or their interaction effects with justice. I also tested 


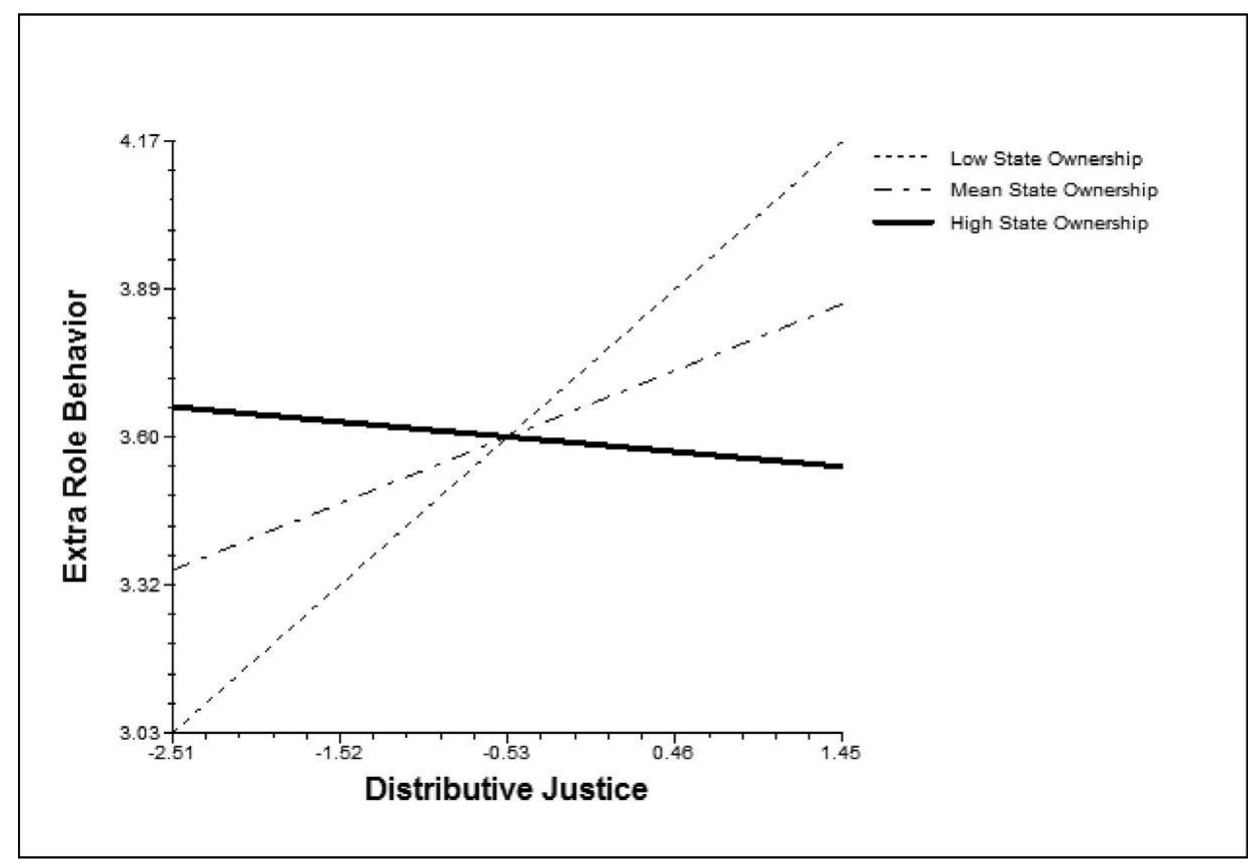

Figure 3. The interaction effect of distributive justice and state ownership on extra-role behavior.

whether the hypothesized interaction effects were robust after controlling for the role behavior, and this effect was not moderated by state ownership $(b=-0.35$, s.e. $=0.23, \mathrm{p}=0.12$ ). After controlling for the main effect of interactional justice, the hypothesized moderation effects remained significant. ${ }^{[3]}$ Therefore, the results were robust to individual difference in cultural values and interactional justice $\quad 744$ individuals receive.

\section{DISCUSSION}

Drawing on the institutional diversity in the reform context of China, this study demonstrates that ownership structure moderates the effects of justice on extrarole behavior. Specifically, distributive justice is positively associated with extra effect after controlling for individual values and interactional justice) in highly state-owned organizations. In contrast, participation in decision making - a key component of procedural justice - is positively associated with extra-role behavior became non-significant in highly privatized companies. The moderation effect 

behavior depends on perceived justice. Specifically, employees of privatized organizations demonstrate less extra-role behavior than SOE employees when distributive justice is low, whereas SOE employees engage in less extra-role behavior than employees of privatized organizations when they perceive low procedural justice or high distributive justice. In other words, people react negatively when their dominant relational schema is not verified, but people in different organizations react differently to practices that are inconsistent with their schemas, depending on whether such practice is irrelevant or contradictory to their schemas. Since participation is irrelevant to privatized companies' market pricing schema, it is ignored by their employees, and their extra-role behavior is not reduced. In contrast, distributive justice is not only inconsistent with SOEs' communal sharing schema, it contradicts that schema by undermining the equal status of employees. As a result, employees of SOEs engage in less extra-role behavior than privatized companies when distributive justice is high.

\section{Theoretical Contributions}

776

This study makes important theoretical contributions to multiple literatures. First, this study contributes to research on the micro-foundations of corporate governance. Research on corporate governance has called for more attention to the role of labor and research on the transition economies (Aguilera \& Jackson, 2010; Fiss, 2008). Many countries' SOEs have employee representatives on board (World Bank, 2014), and even more organizations have various forms of worker participation, such as employee stock ownership plans (Doucouliagos, 1995). This study suggests that these organizations should pay attention to the unique relational schema triggered by these institutions. Increasing labor representation in corporate governance can change the nature of how employees relate to their organizations. Employees will regard themselves as owners of organizations and attend to participation opportunities to verify their owner identity. Meanwhile, they will be less sensitive to the outcomes they receive. Therefore, even minor and symbolic change in corporate governance can have far-reaching implications for employee motivation.

In addition, I offer a theory of the micro foundations of institutional transition. I find that the relationship between perceived justice and individual behavior depends upon ownership structure and, likewise, the relationship between ownership structure and individual behavior depends upon justice perceptions. Thus, the favored variables of micro and macro scholars do not work independently - they combine interactively to influence individual behaviors. I found that ownership structure is not associated with different levels of employee motivation (Burawoy \& Lukacs, 1985), but rather associated with different predictors of employee motivation. This finding helps explain the mixed results on the transition effect. Since the transition effect depends 
on how people perceive organizational practices, the method of transition may greatly influence its effectiveness. For instance, previous research found

Furthermore, this study discovers a boundary condition of the well-established 808 effects of organizational justice. Previous research has proposed at least two $\quad 809$ reasons for why justice is important - instrumental reason represented by 810 social exchange theory and relational reason represented by social identity 811 theory. The current study suggests that justice is important for different reasons $\quad 812$ under different organizational contexts, and distributive justice and procedural $\quad 813$ justice are differentially positioned to serve people's instrumental or relational $\quad 814$ needs. Specifically, when organizational contexts foster a communal sharing $\quad 815$ schema, the function of procedural justice in satisfying individuals' relational 816 needs and verifying their social identity is especially important. In these 817 contexts, the well-established positive effect of distributive justice becomes non- $\quad 818$ significant or even reversed. In contrast, when organizational contexts emphasize $\quad 819$ productivity and efficiency, distributive justice plays an important role in fulfilling 820 people's instrumental motive. Therefore, this study highlights the importance $\quad 821$ of organizational context and its underlying relational model as factors that $\quad 822$ shape why people care about justice and which aspect of justice people care $\quad 823$ about.

Finally, this study contributes to cross-cultural research by highlighting the importance of organizational context and relational model in activating cultural knowledge and guiding individual behaviors. Cross-cultural research has investigated how national differences in cultural values influence individuals' reactions to justice (Kirkman, Chen, Farh, Chen, \& Lowe, 2009). However, studies relying on different cultural values generate conflicting predictions regarding how people within the same culture react to justice. For instance, since Chinese are high on both materialism and interdependent self-construal, both distributive justice and procedural justice should be important for them (Brockner et al., Chinese people are high in power distance and traditional values, justice especially procedural justice - should be less important for them (Brockner et al., 2001; Farh, Earley, \& Lin, 1997; Kim \& Leung, 2007). These contradictions are not specific to China. Given that power distance and collectivism are highly correlated with each other (Hofstede, 2001), it would be challenging 
844 2009). It is the specific context within a culture that determines which relational 845 model is salient. As found in this study, organizational context provides a

846 better prediction about organizational members' reaction to justice than cultural 847 values.

\section{Implications for Management Practices}

849 First, this study generates important implications for applying justice practices.

850 This study suggests that distributive justice is especially suitable for satisfying 851 instrumental need, whereas procedural justice is especially important for satisfying 852 relational need. Thus, organizations may emphasize different aspects of justice 853 under different organizational agenda. If organizations aim to achieve high 854 productivity, they should emphasize distributive justice and use practices such 855 as performance evaluations and pay for performance. If organizations want to 856 solicit employee identification, they should emphasize procedural justice and 857 establish institutions for employees to participate in organizational decision 858 making.

859 In addition, this study generates new insights for transition economies such 860 as China by emphasizing the perspective of employees in reform design. The 861 institutions of state ownership cultivated a communal sharing schema among 862 SOE employees. As a consequence, they do not react positively to distributive 863 practices such as pay for performance because it contradicts their identity as 864 enterprise masters. Therefore, managers and policymakers should recognize this 865 relational schema while changing the incentive system of SOEs. Just as the 866 manager in Case 3 did, managers should transform employees' relational schemas 867 through training and communication before implementing practice change. At 868 the same time, this sense of ownership can be regarded as a unique legacy 869 of SOEs and be leveraged to their transformation. Reform methods such as 870 profit sharing and employee stock ownership can protect employees' collective 871 identity and reinforce its motivating force. In addition, the reform process should 872 also preserve SOE employees' social identity by inviting them to participate in 873 the design and implementation of the reform. If the reform simply privatizes 874 SOEs and discharges workers without recognizing their relational schema, the 875 reform will encounter unforeseen resistance and lose the motivational legacy of 876 SOEs.

\section{$877 \quad$ Limitations and Future Research}

878 Despite the important contributions, this study has some limitations. First, although 879 the degree of state ownership was measured with archival data, the measurement of 880 justice and extra-role behaviors may be subject to common-method bias. However, 881 'in the absence of true effects, it is extremely unlikely for common-method 882 variance to generate significant cross-level interactions. In fact, if a true cross-level 

common-method variance cannot explain the existence of non-significant simple

Second, although I have conducted qualitative studies to investigate the 891 relational schemas under different ownership structures, I did not measure relational models in the quantitative study. The primary reason for this limitation is because the existing scales are targeted to interpersonal relationships and not suitable for the current study. This limitation makes it difficult to rule out employees. This alternative explanation is not consistent with previous research

Another limitation is that the cross-sectional study could not make causal 915 argument about the observed relationships. However, the unique design of this 916 study reduces the likelihood of reverse causality. In the sample design, all the 917 organizations used to be SOEs, and the majority of the participants used to be SOE 918 employees. Because the reform in Shanghai was carried forward with close state 919 control, the labor transfer between organizations during transition was controlled $\quad 920$ by the state and kept at a minimum level. Thus, the different relationships between 921 justice and extra-role behaviors observed in different organizations are more $\quad 922$ attributable to ownership change than individual self-selection. Future research $\quad 923$ can employ longitudinal study to track individual behaviors during the reform and 924 corroborate my findings. 
927 Drawing on the institutional diversity during ownership reform in China, this 928 study shows that the ownership structure of organizations influences why people care about justice and which aspect of justice people value. In state-owned organizations, the socialist legacy activates a communal sharing schema among employees and renders participation an important factor for verifying their social identity. As the privatization reform emphasizes productivity and efficiency, employees of privatized organizations construe their relationships with their organizations as social exchanges and pay close attention to equitable allocation of outcomes. Therefore, policymakers and managers should acknowledge the different schemas activated by different ownership structures and design reform methods and management practices creatively.

\section{NOTES}

I want to thank Batia M. Wiesenfeld, Gino Cattani, Elizabeth W. Morrison, and Steven L. Blader et al. for their generous help and great suggestions on previous versions of the article. I also want to I highly appreciate the resources provided by Doug Guthrie and Zhixing Xiao and administrative support of Shanghai State-Owned Assets Supervision and Administration Commission (SASAC).

[1] A critical subset of extra-role behaviors are organizational citizenship behaviors (OCB's; Van Dyne et al., 1995). The present research is designed to explore extra-role behaviors but, in some instances, the literature that I draw upon focuses on specific categories of extra-role behaviors, especially OCB's.

[2] The results are in the same pattern when centering distributive justice and procedural justice on their grand means.

[3] After controlling for the effects of interactional justice and cultural values, the simple slope of procedural justice did not change much. The simple slope of distributive justice was significantly positive when degree of state ownership was lower than 0.37 and became significantly negative when the degree of state ownership was higher than 0.67 .

\section{REFERENCES}

Adams, J. S. 1965. Inequity in social exchange. Advances in Experimental Social Psychology, 2: $267-299$.

Aguilera, R. V., \& Jackson, G. 2010. Comparative and international corporate governance. The Academy of Management Annals, 4(1): 485-556.

Aguinis, H., Gottfredson, R. K., \& Culpepper, S. A. 2013. Best-practice recommendations for estimating cross-level interaction effects using multilevel modeling. Journal of Management, 39(6): 1490-1528.

Bai, C., \& Wang, Y. 1998. Bureaucratic control and the soft budget constraint. Journal of Comparative Economics, 26(1): 41-61.

Benson, J., \& Zhu, Y. 1999. Markets, firms and workers in Chinese state-owned enterprises. Human Resource Management Journal, 9(4): 58-74.

Bies, R. J., \& Shapiro, D. L. 1988. Voice and justification: Their influence on procedural fairness judgments. Academy of Management Journal, 31(3): 676-685.

Blader, S. L., \& Tyler, T. R. 2003a. A four-component model of procedural justice: Defining the meaning of a fair process. Personality and Social Psychology Bulletin, 29(6): 747-758.

Blader, S. L., \& Tyler, T. R. 2003b. What constitutes fairness in work settings? A four-component model of procedural justice. Human Resource Management Review, 13(1): 107-126. 
Blader, S. L., \& Tyler, T. R. 2009. Testing and extending the group engagement model: Linkages between social identity, procedural justice, economic outcomes, and extrarole behavior. Journal of Applied Psychology, 94(2): 445-464.

Brislin, R. W. 1980. Translation and content analysis of oral and written material. Handbook of Cross-cultural Psychology, 2: 389-444.

Brockner, J., Ackerman, G., Greenberg, J., Gelfand, M. J., Francesco, A. M., Chen, Z. X., Leung, K., Bierbrauer, G., Gomez, C., Kirkman, B. L., \& Shapiro, D. 2001. Culture and procedural justice: The influence of power distance on reactions to voice. Journal of Experimental Social Psychology, 37(4): 300-315.

Brockner, J., Chen, Y.-R., Mannix, E. A., Leung, K., \& Skarlicki, D. P. 2000. Culture and procedural fairness: When the effects of what you do depend on how you do it. Administrative Science Quarterly, 45(1): 138-159.

Brockner, J., De Cremer, D., van den Bos, K., \& Chen, Y.-R. 2005. The influence of interdependent self-construal on procedural fairness effects. Organizational Behavior and Human

Decision Processes, 96(2): 155-167.

Bruton, G. D., Peng, M. W., Ahlstrom, D., Stan, C., \& Xu, K. 2015. State-owned enterprises around the WORLD as hybrid organizations. The Academy of Management Perspectives, 29(1): 92-114.

Burawoy, M., \& Lukacs, J. 1985. Mythologies of work: A comparison of firms in state socialism and advanced capitalism. American Sociological Review, 50(6): 723-737.

Chen, C. C., Meindl, J. R., \& Hui, H. 1998. Deciding on equity or parity: A test of situational, cultural, and individual factors. Journal of Organizational Behavior, 19(2): 115-129.

Chen, J. 2001. Ownership structure as corporate governance mechanism: Evidence from Chinese listed companies. Economics of Planning, 34(1): 53-72.

Chiu, C. C. H. 2006. Changing experiences of work in reformed state-owned enterprises in China. Organization Studies, 27(5): 677-697.

Chiu, W. C. K. 2002. Do types of economic ownership matter in getting employees to commit? An exploratory study in the People's Republic of China. International Journal of Human

Resource Management, 13(6): 865-882.

Choi, J., \& Chen, C. C. 2007. The relationships of distributive justice and compensation system fairness to employee attitudes in international joint ventures. Journal of Organizational Behavior, 28(6): 687-703.

Coase, R. H. 1937. The nature of the firm. Economica, 4(16): 386-405. 2013. Justice at the millennium, a decade later: A meta-analytic test of social exchange and 1011 affect-based perspectives. Journal of Applied Psychology, 98(2): 199-236. 1012

Cross, S. E., Bacon, P. L., \& Morris, M. L. 2000. The relational-interdependent self-construal and 1013 relationships. Journal of Personality and Social Psychology, 78(4): 791-808. 1014

Cuervo, A., \& Villalonga, B. 2000. Explaining the variance in the performance effects of privatization. 1015 The Academy of Management Review, 25(3): 581-590.

Dharwadkar, R., George, G., \& Brandes, P. 2000. Privatization in emerging economies: An agency theory perspective. The Academy of Management Review, 25(3): 650-669.

Dong, X.-Y., \& Putterman, L. 2003. Soft budget constraints, social burdens, and labor redundancy 1019 in China's state industry. Journal of Comparative Economics, 31(1): 110-133. 1020

Doucouliagos, C. 1995. Worker participation and productivity in labor-managed and participatory 1021 capitalist firms: A meta-analysis. Industrial and Labor Relations Review, 49(1): 58-77. 1022

Farh, J. L., Earley, P. C., \& Lin, S.-C. 1997. Impetus for action: A cultural analysis of justice and 1023 organizational citizenship behavior in Chinese society. Administrative Science Quarterly, 1024 42(3): 421-444.

Farh, J. L., Zhong, C.-B., \& Organ, D. W. 2004. Organizational citizenship behavior in the People's Republic of China. Organization Science, 15(2): 241-253.

Fiske, A. P. 1991. Structures of social life: The four elementary forms of human relations: York: Free Press.

Communal sharing, authority ranking, equality matching, market pricing. New 
1031 Fiske, A. P. 1992. The four elementary forms of sociality: Framework for a unified theory of social

1032

1033

1034

1035

1036

1037

1038

1039

1040

1041

1042

1043

1044

1045

1046

1047

1048

1049

1050

1051

1052

1053

1054

1055

1056

1057

1058

1059

1060

1061

1062

1063

1064

1065

1066

1067

1068

1069

1070

1071

1072

1073

1074

1075

1076

1077

1078

1079

1080

1081

1082

1083

1084

1085

1086

1087

1088

1089

relations. Psychological Review, 99(4): 689-723.

Fiss, P. C. 2008. Institutions and corporate governance. In R. Greenwood, C. Oliver, R. Suddaby, \& K. Sahlin (Eds.), The SAGE handbook of organizational institutionalism: 389-410. Thousand Oaks, CA: Sage Publications.

Friedland, R., \& Alford, R. R. 1991. Bringing society back in: Symbols, practices, and institutional contradictions. In W. W. Powell \& P. J. DiMaggio (Eds.), The new institutionalism in organizational analysis: 232-263. Chicago: University of Chicago Press.

Giacobbe-Miller, J. K., Miller, D. J., \& Zhang, W. 1997. Equity, equality and need as determinants of pay allocations: A comparative study of Chinese and US managers. Employee Relations, 19(4): 309-320.

Giacobbe-Miller, J. K., Miller, D. J., Zhang, W., \& Victorov, V. I. 2003. Country and organizationallevel adaptation to foreign workplace ideologies: A comparative study of distributive justice values in China, Russia and the United States. Journal of International Business Studies, 34(4): 389-406.

Gong, Y., \& Chang, S. 2008. Institutional antecedents and performance consequences of employment security and career advancement practices: Evidence from the People's Republic of China. Human Resource Management, 47(1): 33-48.

Groves, T., Yongmiao, H., McMillan, J., \& Naughton, B. 1994. Autonomy and incentives in Chinese state enterprises. Quarterly Journal of Economics, 109(1): 183-209.

Guthrie, D. 1999. Dragons in a three-piece suit: The emergence of capitalism in China: Princeton, NJ: Princeton University Press.

Guthrie, D. 2002. The transformation of labor relations in China's emerging market economy. Research in Social Stratification and Mobility, 19(0): 139-170.

Hage, J., \& Aiken, M. 1969. Routine technology, social structure, and organization goals. Administrative Science Quarterly, 14(3): 366-376.

Haslam, N., \& Fiske, A. P. 1999. Relational models theory: A confirmatory factor analysis. Personal Relationships, 6(2): 241-250.

Hassard, J., Morris, J., \& Sheehan, J. 2002. The elusive market: Privatization, politics and stateenterprise reform in China. British Journal of Management, 13(3): 221-231.

Hassard, J., Morris, J., Sheehan, J., \& Yuxin, X. 2006. Downsizing the danwei: Chinese stateenterprise reform and the surplus labour question. International Journal of Human Resource Management, 17(8): 1441-1455.

He, W., Chen, C. C., \& Zhang, L. 2004. Rewards-allocation preferences of Chinese employees in the new millennium: The effects of ownership reform, collectivism, and goal priority. Organization Science, 15(2): 221-231.

Hill, C. W. L., \& Snell, S. A. 1989. Effects of ownership structure and control on corporate productivity. Academy of Management Journal, 32(1): 25-46.

Hofstede, G. H. 2001. Culture's consequences: Comparing values, behaviors, instiPublications, Inc. tutions, and organizations across nations (2nd ed.). Thousand Oaks, CA: Sage Routledge.

Hox, J. 2010. Multilevel analysis: Techniques and applications (2nd ed.). New York:

Hui, C., Lam, S. S. K., \& Law, K. K. S. 2000. Instrumental values of organizational citizenship behavior for promotion: A field quasi-experiment. Journal of Applied Psychology, 85(5): $822-828$.

Jackson, C. L., Colquitt, J. A., Wesson, M. J., \& Zapata-Phelan, C. P. 2006. Psychological collectivism: A measurement validation and linkage to group member performance. Journal of Applied Psychology, 91(4): 884-898.

Jackson, S. 1992. Chinese enterprise management: Reforms in economic perspective. New York: Walter de Gruyter.

Keister, L. A. 2002. Adapting to radical change: Strategy and environment in piece-rate adoption during China's transition. Organization Science, 13(5): 459-474.

Kim, T.-Y., \& Leung, K. 2007. Forming and reacting to overall fairness: A cross-cultural comparison. Organizational Behavior and Human Decision Processes, 104(1): 83-95.

Kirkman, B. L., Chen, G., Farh, J. L., Chen, Z. X., \& Lowe, K. B. 2009. Individual power distance orientation and follower reactions to transformational leaders: A cross-level, cross-cultural examination. Academy of Management Journal, 52(4): 744-764. 
Kwong, J. Y. Y., \& Leung, K. 2002. A moderator of the interaction effect of procedural justice 1090 and outcome favorability: Importance of the relationship. Organizational Behavior and 1091 Human Decision Processes, 87(2): 278-299.

La Porta, R., Lopez-De-Silanes, F., \& Shleifer, A. 1999. Corporate ownership around the world. The 1093 Journal of Finance, 54(2): 471-517.

1094

Lai, X., Li, F., \& Leung, K. 2013. A Monte Carlo study of the effects of common method variance 1095 on significance testing and parameter bias in hierarchical linear modeling. Organizational 1096 Research Methods, 16(2): 243-269.

1097

Le, T. V., \& Buck, T. 2009. State ownership and listed firm performance: A universally negative 1098 governance relationship? Journal of Management \& Governance, 15(2): 227-248. 1099

Le, T. V., \& O’Brien, J. P. 2010. Can two wrongs make a right? State ownership and debt in a 1100 transition economy. Journal of Management Studies, 47(7): 1297-1316. 1101

Li, S., Xia, J., Long, C. X., \& Tan, J. 2012. Control modes and outcomes of transformed state- 1102 owned enterprises in China: An empirical test. Management and Organization Review, 1103 8(2): 283-309.

Lin, N. 2011. Capitalism in China: A centrally managed capitalism (CMC) and its future. 1105 Management and Organization Review, 7(1): 63-96.

1106

Lind, E. A. 2001. Fairness heuristic theory: Justice judgments as pivotal cognitions in organizational 1107 relations. In J. Greenberg \& C. Russell (Eds.), Advances in organizational justice: 56-88. 1108 Stanford: Stanford University Press.

Lind, E. A., Kray, L., \& Thompson, L. 2001. Primacy effects in justice judgments: Testing

1109 predictions from fairness heuristic theory. Organizational Behavior and Human Decision Processes, 85(2): 189-210.

Lind, E. A., \& Tyler, T. R. 1988. The social psychology of procedural justice. New York: Springer US.

1110

1111

1112

1113

1114

$\begin{array}{cr}\text { Lind, E. A., Tyler, T. R., \& Huo, Y. J. 1997. Procedural context and culture: Variation in } & 1115 \\ \text { the antecedents of procedural justice judgments. Journal of Personality and Social } & 1116\end{array}$ Psychology, 73(4): 767-780.

Liu, S. 2003. Cultures within culture: Unity and diversity of two generations of employees in stateowned enterprises. Human Relations, 56(4): 387-417.

1117

1118

1119

1120

MacKenzie, S. B., Podsakoff, P. M., \& Fetter, R. 1991. Organizational citizenship behavior and objective productivity as determinants of managerial evaluations of salespersons' performance. Organizational Behavior and Human Decision Processes, 50(1): 123-150.

Mok, K.-H., Wong, L., \& Lee, G. O. M. 2002. The challenges of global capitalism: Unemployment and state workers' reactions and responses in post-reform China. International Journal of Human Resource Management, 13(3): 399-415.

Moorman, R. H., \& Blakely, G. L. 1995. Individualism-collectivism as an individual difference predictor of organizational citizenship behavior. Journal of Organizational Behavior, 16(2): $127-142$.

Morrison, E. W. 1994. Role definitions and organizational citizenship behavior: The importance of the employee's perspective. The Academy of Management Journal, 37(6): 1543-1567.

Naughton, B. 1996. Growing out of the plan: Chinese economic reform, 1978-1993. Cambridge, UK: Cambridge University Press.

Naughton, B. 2005. SASAC rising. China Leadership Monitor, 14: 1-11.

Nee, V. 1992. Organizational dynamics of market transition: Hybrid forms, property rights, and mixed economy in China. Administrative Science Quarterly, 37(1): 1-27.

Ngo, H. Y., Lau, C. M., \& Foley, S. 2008. Strategic human resource management, firm performance, and employee relations climate in China. Human Resource Management, 47(1): 73-90.

Organ, D. W. 1990. The motivational basis of organizational citizenship behavior. Research in Organizational Behavior, 12(1): 43-72.

Organ, D. W., Podsakoff, P. M., \& MacKenzie, S. B. 2006. Organizational citizenship behavior: Its nature, antecedents, and consequences. Thousand Oaks, CA: Sage Publications.

Pargendler, M. 2012. State ownership and corporate governance. Fordham Law Review, 80(6): 2917-2973.

Parker, D. 1995. Privatization and agency status: Identifying the critical factors for performance improvement. British Journal of Management, 6(1): 29-43.

1121

1122

1123

1124

1125

1126

1127

1128

1129

1130

1131

1132

1133

1134

1135

1136

1137

1138

1139

1140

1141

1142

1143

1144

1145

1146

Peng, M. W., Bruton, G. D., Stan, C. V., \& Huang, Y. 2016. Theories of the (state-owned) firm. Asia 1147 Pacific Journal of Management, 33(2): 293-317. 
1149 Podsakoff, N. P., Whiting, S. W., Podsakoff, P. M., \& Blume, B. D. 2009. Individual-and 1150 organizational-level consequences of organizational citizenship behaviors: A meta-analysis.

$1151 \quad$ Journal of Applied Psychology, 94(1): 122-141.

1152 Podsakoff, P. M., MacKenzie, S. B., Jeong-Yeon, L., \& Podsakoff, N. P. 2003. Common method biases

1153 in behavioral research: A critical review of the literature and recommended remedies. Journal

1154 of Applied Psychology, 88(5): 879-903.

1155 Podsakoff, P. M., MacKenzie, S. B., Paine, J. B., \& Bachrach, D. G. 2000. Organizational citizenship

1156 behaviors: A critical review of the theoretical and empirical literature and suggestions for future

1157 research. Journal of Management, 26(3): 513-563.

1158 Preacher, K. J., Curran, P. J., \& Bauer, D. J. 2006. Computational tools for probing interactions

1159 in multiple linear regression, multilevel modeling, and latent curve analysis. Journal of

$1160 \quad$ Educational and Behavioral Statistics, 31(4): 437-448.

1161 Ralston, D. A., Terpstra-Tong, J., Terpstra, R. H., Wang, X., \& Egri, C. 2006. Today's state-owned

1162 enterprises of China: Are they dying dinosaurs or dynamic dynamos? Strategic Management

1163 Journal, 27(9): 825-843.

1164 Ramamurti, R. 2000. A multilevel model of privatization in emerging economies. The Academy of

1165 Management Review, 25(3): 525-550.

1166 Ramaswamy, K. 2001. Organizational ownership, competitive intensity, and firm performance: An

1167 empirical study of the Indian manufacturing sector. Strategic Management Journal, 22(10): 1168 989-998.

1169 Realo, A., Kästik, L., \& Allik, J. 2004. The relationships between collectivist attitudes and elementary 1170 forms of human relations: Evidence from Estonia. Journal of Social and Personal $1171 \quad$ Relationships, 21(6): 779-794.

1172 Sanchez-Burks, J., Nisbett, R. E., \& Ybarra, O. 2000. Cultural styles, relationship schemas, and prejudice against out-groups. Journal of Personality and Social Psychology, 79(2): 174-

1175 SASAC. 2008. Shanghai state-owned assets statistical yearbook: 88-102: Shanghai state-owned assets

1176 supervision and administration commission.

1177 Seo, M.-G., \& Creed, W. E. D. 2002. Institutional contradictions, praxis, and institutional change: A 1178 dialectical perspective. The Academy of Management Review, 27(2): 222-247.

1179 Tang, W. F. 1993. Workplace participation in Chinese local industries. American Journal of $1180 \quad$ Political Science, 37(3): 920-940.

\section{1}

1182

1183

1184

1185

1186

1187

1188

1189

1190

1191

1192

1193

1194

1195

1196

1197

1198

1199

1200

1201

1202

1203

1204

1205

1206

1207

The Economist. 2012. The rise of state capitalism, Vol. 402: 11-12. London: The Economist Intelligence Unit N.A., Incorporated.

Thornton, P. H., Ocasio, W., \& Lounsbury, M. 2012. The institutional logics perspective: A new approach to culture, structure, and process. Oxford: Oxford University Press.

Tsai, C.-J., \& Wang, W.-L. 2013. Exploring the factors associated with employees' perceived appraisal accuracy: A study of Chinese state-owned enterprises. International Journal of Human Resource Management, 24(11): 2197-2220.

Tyler, T. R. 1989. The psychology of procedural justice: A test of the group-value model. Journal of Personality and Social Psychology, 57(5): 830-838.

Tyler, T. R. 1994. Psychological models of the justice motive: Antecedents of distributive and procedural justice. Journal of Personality and Social Psychology, 67(5): 850-863.

Tyler, T. R., \& Blader, S. L. 2000. Cooperation in groups: Procedural justice, social identity, and behavioral engagement. Philadelphia, PA: Psychology Press.

Tyler, T. R., \& Blader, S. L. 2003. The group engagement model: Procedural justice, social 349-361. identity, and cooperative behavior. Personality and Social Psychology Review, 7(4):

Tyler, T. R., Degoey, P., \& Smith, H. 1996. Understanding why the justice of group procedures matters: A test of the psychological dynamics of the group-value model. Journal of Personality and Social Psychology, 70(5): 913-930.

Tyler, T. R., \& Lind, E. A. 1992. A relational model of authority in groups. Advances in Experimental Social Psychology, 25: 115-191.

Van Dyne, L., Cummings, L. L., \& Parks, J. M. 1995. Extra-role behaviors: In pursuit of construct and definitional clarity (a bridge over muddied waters). Research in Organizational Behavior, 17: 215-215.

Vodosek, M. 2009. The relationship between relational models and individualism and collectivism: Evidence from culturally diverse work groups. International Journal of Psychology, 44(2): $120-128$. 
Walder, A. G. 1981. Participative management and worker control in China. Sociology of Work 1208 and Occupations, 8(2): 224-251. 1209

Walder, A. G. 1983. Organized dependency and cultures of authority in Chinese industry. The 1210

Journal of Asian Studies, 43(1): 51-76. 1211

Walder, A. G. 1989. Social change in post-revolution China. Annual Review of Sociology, 15: 1212 405-424.

1213

Walder, A. G. 1995. China's transitional economy: Interpreting its significance. The China 1214 Quarterly, 144: 963-979.

1215

Walder, A. G. 2011. From control to ownership: China's managerial revolution. Management and 1216

Organization Review, 7(1): 19-38.

1217

Wang, B., \& Greenwood, K. M. 2015. Psychological responses to lay-off in contemporary China. 1218

International Journal of Human Resource Management, 26(3): 361-380. 1219

Wang, Y. 2004. Observations on the organizational commitment of Chinese employees: Comparative 1220 studies of state-owned enterprises and foreign-invested enterprises. The International 1221

Journal of Human Resource Management, 15(4-5): 649-669.

Williamson, O. E. 1981. The economics of organization: The transaction cost approach. The 1223 American Journal of Sociology, 87(3): 548-577.

1224

1225

1226

1227

1228

1229

1230

1231

1232

1233

1234

1235

1236

1237

1238

Xi Chen (xi.chen2@nottingham.edu.cn) is an assistant professor of Organizational Behavior and Human Resource Management at the Department of International Business and Management of Nottingham University Business Ningbo, China. Her research explores how the macro and micro phenomena interact and influence each other. On the one hand, she studies how organizational ownership structure influences employees' behaviors and reactions to organizational practices. On the other hand, she studies how individuals' motives, such as self-enhancement motive, influence organizational and entrepreneurial behaviors.

Manuscript received: July 5, 2016

Final version accepted: December 8, 2017 (number of revisions - 3) 